\title{
Study of sperm head abnormalities of UV exposured mice which treated by Eruca sativa
}

\author{
Amel Mustafa Kamel (Ms.C.) \\ College of Health and Medical Technologies Iraq-Baghdad.
}

\begin{abstract}
In this study, 60 mice were used which divided into two groups, 20 mice control group, 40 mice employed to study of the effect of UVC radiation for one hour/ one day. These mice were left for one day as rest time before treatment with intended seed oil. 20 of these mice were treated with $0.5 \mathrm{ml}$ oral dose from Eruca sativa seed oil (ESO) daily for 21 successive.

Sperm head abnormalities induced by uvc radiation and The impact of plant oil in the treatment of sperm head abnormalities (no head, ballon head, thread head, and no head curved tail) were studied in this experiment by using (ESO) which is comprise a range of health-promoting phytochemicals including carotenoids, vitamin $C$, fibers, flavonoids, glucosinolates, and a large amount of thiofunctionalized glucosinolates along with erucic acid C22:1 (cis-13-docosenoic acid).

10 mice killed from first group(control), 10 mice killed from radiated micsa

10 mice killed after 15 and 21 days of treatment by ESO for sampling

The results showing significant effect of radiation on the head abnormalities and highly significant effect of ESO on the sperm head abnormalities after 15 and 20 days.
\end{abstract}

Key words: ESO, sperm abnormalities, UVC radiation, mice.

\section{Introduction}

UV light is electromagnetic radiation with a wave length shorter than that of visible light, but longer than $\mathrm{X}$ - rays, in the range $10 \mathrm{~nm} 400 \mathrm{~nm}$. Its classify into three types or bands: UVA (wavelength $320-400 \mathrm{~nm}$ not absorbed by the ozone layer), UVB (wavelength 290-320 nm mostly absorbed by the ozone layer, but some can reach to the earth surface), UVC( wavelength $100-290 \mathrm{~nm}$ Completely absorbed by the ozone layer and atmosphere)[1].

UV irradiation can impair cellular functions by directly damaging DNA to induce apoptosis [2]. Among other things, longer UV wavelengths (UVB, UVA) induce oxidative stress and protein denaturation whereas short wavelength UV radiation (UVC) causes predominantly DNA damage to cells in the form of pyrimidine dimers, $6-4$ photoproducts and apoptosis $[3,4]$.

The basic of sperm is stream of genetic information, intuitively the change in the chromosome content may cause variation in the size of sperm, the result from these research refers to relation between genetic and morphology of sperm[5].The causes of sperm abnormalities may be environmental, genetic or both of them .but the environmental causes is more common, these causes have been associated with male infertility and fail to conception [6].

Sperm abnormalities are classified into two groups , primary and secondary abnormalities depending to their presumptive origin. All defects which occur during spermatogenesis are considered as primary and those developing subsequent to spermiation considered as secondary [7]. Sperm abnormalities classified as defects in the head, middle piece or tail of sperm[8].

All civilization used plants as sources of food because of their essential nutritional value ,and because of their physiological effect, they use it as a pharmaceutical materials[9]. so they considered as complementary and alternative medicine. Some of these plants have aphrodisiac effect like eruca sativa which increase its utilization among patients seeking infertility treatment. Infertile patients are vulnerable group that often seek a non- medical solution for their failure to conceive [10].

Eruca sativa a member of Brassicaceae family, is commonly referred as "rocket, true rocket, rocket salad, arugula, roquette, or white pepper" in English. Eruca is a native of southern Europe and central Asia where it has been cultivated since classical times. .[3]

Eruca seeds contain a large amount of thiofunctionalized glucosinolates along with erucic acid C22:1 (cis-13docosenoic acid).[11,12]

Eruca sativa seed (ESS) oil contains a range of health-promoting phytochemicals including carotenoids, vitamin C, fibers, flavonoids, and glucosinolates (GLs) and their breakbown products, e.g. isothiocyanates (as sulforaphane) [13]. Sulforaphane has several biological activities including anticarcinogenic, antifungal, antibacterial and antioxidant effects [14]. 
Animals:

\section{Material and methods:}

An experiment was carried out on 60 White mice(Mus musculus) at (8-12)week and weight (30 - 35) $\mathrm{g}$ which is equeped at the (Animal breeding center college of Medicin - Baghdad University)and distributed into cages at need to experience and for duration of trails was to give animals water and bush integrated and manufactured by the Center of IPA for agrucltural Research in ABU Ghraib - Baghdad.All animals were placed in the room ranged temperature (20-25) ${ }^{0} \mathrm{c}$ and lighting ranged (12)h light and (12)h darkness.

\section{Eruca sativa seeds oil (ESO):}

Eruca sativa seeds oil used in the study was provided by EMAD factory to plant oil production Mosul $\backslash$ Iraq placed in the dark bottle in $100 \%$ concentration.

\section{Experimental design:}

The mice were divided into two groups as the following:

-First group consist of 20 mice kept under basal diet, water, light without any treatment which considers as control group.

-Second group consist of 40 mice employed to study the effect of UVC light and ESO on the sperm heads.

These mice exposed to one for one day to the UVC radiation, and left the next day to rest. After rest time oral dose from $0.5 \mathrm{ml}$ of ESO was given daily to the mice for 21 successive days.

Sampling: 10 mice killed from first group(control), 10 mice killed from radiated mice

10 mice killed after 15 and 21 days of treatment with ESO, extract sperm from epididymis.

Sperm head abnormalities test

This examination was according to Wyrobek and Bruce (1975) to extract sperm from epididymis of mice[15].

\section{Result:}

In this study there are four sperm head abnormalities: no head, thread head, balloon head and curved head \& no hook [Fig-1].

To study the sperm head abnormalities when exposure to UVC and treated with ESO which are summarized in the $[$ Table-1,2,3].

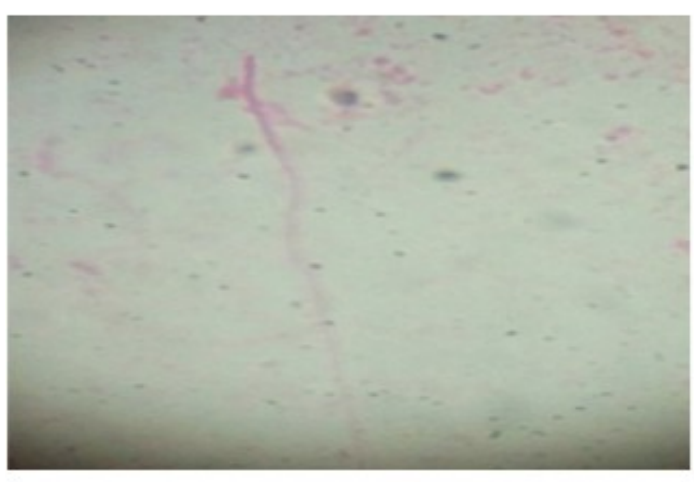

b- No head sperm

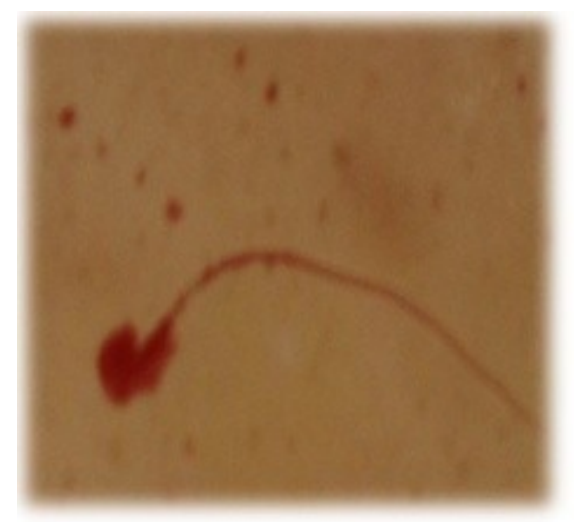

c- Balloon head sperm

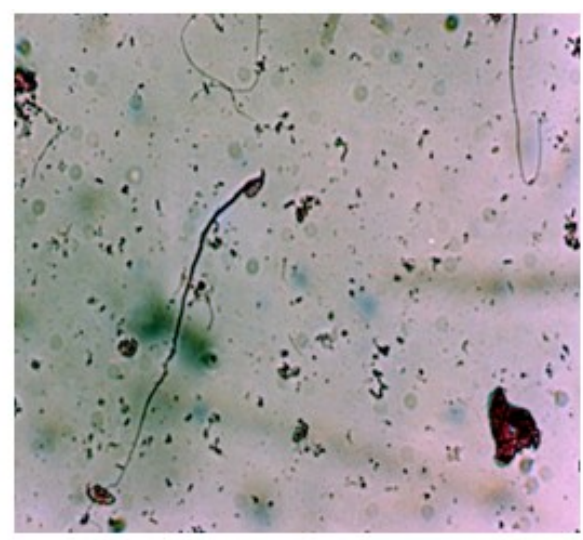

a- Normal sperm

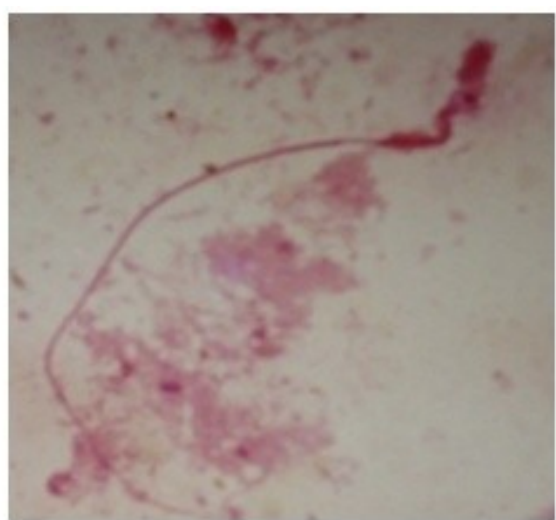

d-Thread head sperm 


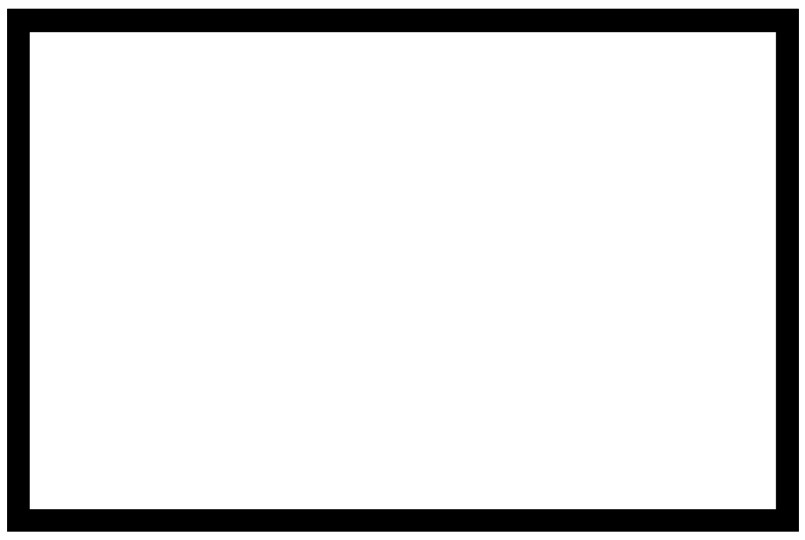

e- Curved head \& No hook sperm

Figure (1) Types of sperm head abnormalities

a- $\quad$ Normal sperm, b- No head sperm, c- Balloon sperm, d- Thread sperm and

e- Curved head \& No hook sperm.

Table-1- effect of UVC radiation on the White Mice(Mus musculus) .

\begin{tabular}{|c|c|c|c|c|c|c|c|c|}
\hline & \multicolumn{5}{|c|}{ Uv } & \multirow[b]{2}{*}{ Total } \\
\hline & & & normal & $\begin{array}{c}\text { No } \\
\text { head }\end{array}$ & $\begin{array}{c}\text { Balloon } \\
\text { head }\end{array}$ & \begin{tabular}{c|}
$\begin{array}{c}\text { Thread } \\
\text { head }\end{array}$ \\
\end{tabular} & $\begin{array}{l}\text { No head } \\
\text { curved tail }\end{array}$ & \\
\hline \multirow{9}{*}{ Control } & normal & \begin{tabular}{|l|}
$N$ \\
$\%$
\end{tabular} & $\begin{array}{c}15 \\
15 \%\end{array}$ & $\begin{array}{c}20 \\
20 \%\end{array}$ & $\begin{array}{c}30 \\
30 \%\end{array}$ & $\begin{array}{c}10 \\
10 \%\end{array}$ & $\begin{array}{c}20 \\
20 \%\end{array}$ & $\begin{array}{c}95 \\
95 \%\end{array}$ \\
\hline & \multirow{2}{*}{ No head } & $\mathrm{N}$ & 0 & 0 & 0 & 0 & 2 & 2 \\
\hline & & $\%$ & $0 \%$ & $0 \%$ & $0 \%$ & $0 \%$ & $2 \%$ & $2 \%$ \\
\hline & \multirow{2}{*}{ Balloon head } & $\mathrm{N}$ & $\overline{0}$ & 0 & 0 & 0 & 0 & 0 \\
\hline & & $\%$ & $0 \%$ & $0 \%$ & $0 \%$ & $0 \%$ & $0 \%$ & $0 \%$ \\
\hline & \multirow{2}{*}{ Thread head } & $N$ & 0 & 0 & 0 & 0 & 0 & 0 \\
\hline & & $\%$ & $0 \%$ & $0 \%$ & $0 \%$ & $0 \%$ & $0 \%$ & $0 \%$ \\
\hline & \multirow{2}{*}{ No head curved tail } & $\mathrm{N}$ & 0 & 0 & 0 & 0 & 3 & 3 \\
\hline & & $\%$ & $0 \%$ & $0 \%$ & $0 \%$ & $0 \%$ & $3 \%$ & $3 \%$ \\
\hline \multirow{2}{*}{\multicolumn{2}{|c|}{ Total }} & $\mathrm{N}$ & 15 & 20 & 30 & 10 & 25 & 100 \\
\hline & & $\%$ & $15 \%$ & $20 \%$ & $30 \%$ & $10 \%$ & $25 \%$ & $100 \%$ \\
\hline \multicolumn{4}{|c|}{ Test } & \multicolumn{5}{|c|}{$\mathrm{MCP}<0.05(\mathrm{~S})$} \\
\hline
\end{tabular}

Table-2- effect of UVC radiation and treated with ESO for the White Mice after(15) days

\begin{tabular}{|c|c|c|c|c|c|c|c|c|}
\hline & & & \multicolumn{5}{|c|}{15 days } & \multirow[b]{2}{*}{ Total } \\
\hline & & & normal & No head & $\begin{array}{c}\text { Balloon } \\
\text { head }\end{array}$ & $\begin{array}{c}\text { Thread } \\
\text { head }\end{array}$ & $\begin{array}{c}\text { No head } \\
\text { curved tail }\end{array}$ & \\
\hline \multirow{9}{*}{ UVC } & \multirow{2}{*}{ normal } & $\mathrm{N}$ & 15 & 0 & 0 & 0 & 0 & 15 \\
\hline & & $\%$ & $15 \%$ & $0 \%$ & $0 \%$ & $0 \%$ & $0 \%$ & $15 \%$ \\
\hline & No head & $\begin{array}{l}\mathrm{N} \\
\%\end{array}$ & $\begin{array}{c}20 \\
20 \%\end{array}$ & $\begin{array}{c}0 \\
0 \%\end{array}$ & $\begin{array}{c}0 \\
0 \%\end{array}$ & $\begin{array}{c}0 \\
0 \%\end{array}$ & $\begin{array}{c}0 \\
0 \%\end{array}$ & $\begin{array}{c}20 \\
20 \%\end{array}$ \\
\hline & \multirow{2}{*}{ Balloon head } & $\mathrm{N}$ & 20 & 3 & 7 & 0 & 0 & 30 \\
\hline & & $\%$ & $20 \%$ & $3 \%$ & $7 \%$ & $0 \%$ & $0 \%$ & $30 \%$ \\
\hline & \multirow{2}{*}{ Thread head } & $\mathrm{N}$ & 0 & 0 & 8 & 2 & 0 & 10 \\
\hline & & $\%$ & $0 \%$ & $0 \%$ & $8 \%$ & $2 \%$ & $0 \%$ & $10 \%$ \\
\hline & \multirow{2}{*}{ No head curved tail } & $\mathrm{N}$ & 0 & 0 & 1 & 1 & 23 & 25 \\
\hline & & $\%$ & $0 \%$ & $0 \%$ & $1 \%$ & $1 \%$ & $23 \%$ & $25 \%$ \\
\hline \multirow{2}{*}{\multicolumn{2}{|c|}{ Total }} & $\mathrm{N}$ & 55 & 3 & 16 & 3 & 23 & 100 \\
\hline & & $\%$ & $55 \%$ & $3 \%$ & $16 \%$ & $3 \%$ & $23 \%$ & $100 \%$ \\
\hline \multicolumn{4}{|c|}{ Test } & \multicolumn{5}{|c|}{$\mathrm{MCP} \leq 0.01(\mathrm{HS})$} \\
\hline
\end{tabular}


Table-3- effect of UVC radiation and treated with ESO for the White Mice after (20) days

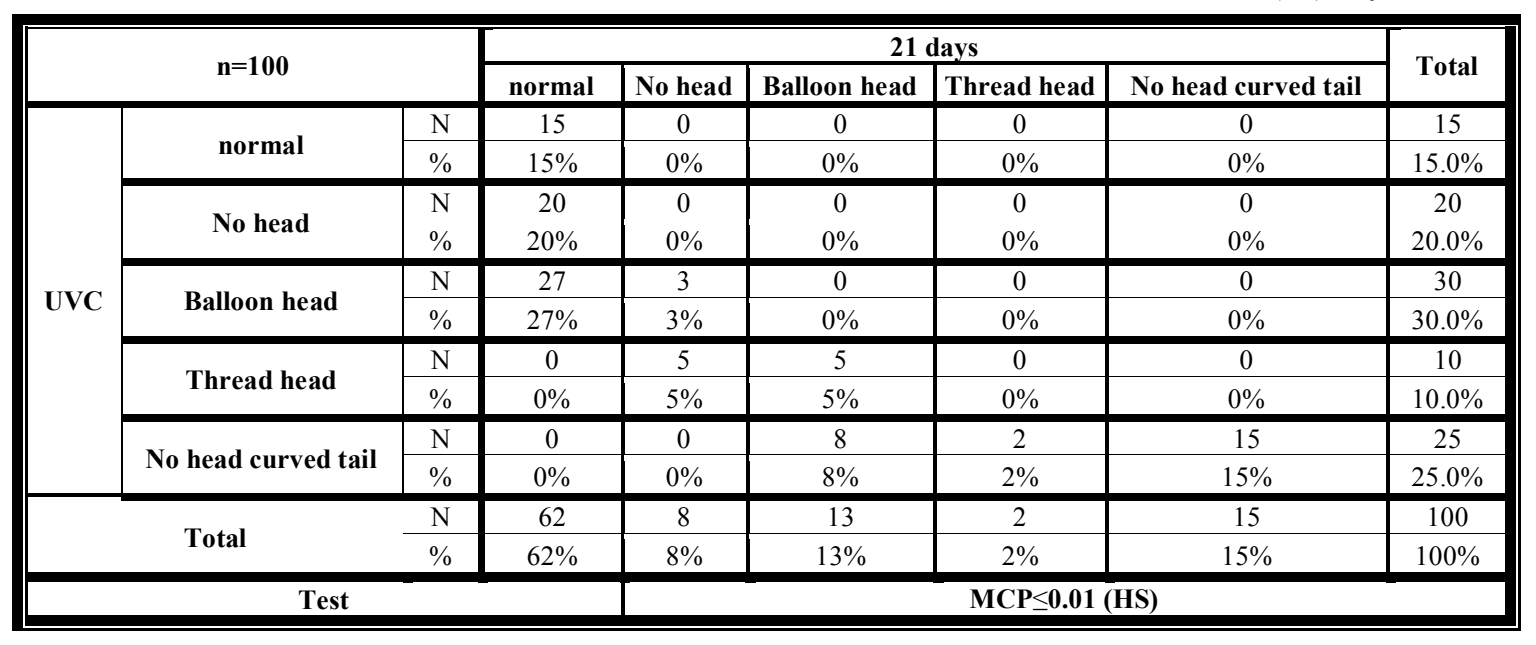

\section{Discussion:}

The UVC radiation is sufficiently energetic that individual photons may produce chemical bond breakage and ionization of some atoms and molecules. The preferential absorption of particular energy photons by materials, both organic and inorganic, is evident throughout the electromagnetic spectrum from microwaves through infrared and visible light, Ultraviolet, X-rays, and Gamma rays [16].

Eruca sativa show a modifying response of cells to UVC radiation. So there is a need to investigate this property In vivo,to investigate the effect treatment with ESO of the UVC $(250 \mathrm{~nm})$ irradiation In vivo on the sperm morphology. In this study there are four sperm head abnormalities: no head, thread head, balloon head and curved head \& no hook [Fig-1].

Table(1) shows the effect of radiation on sperm head abnormalities shows the number of normal cells in the control group was 95 while the no head was 2 and no head and tail was 5 and cell exposure results showed low numbers of normal cells to 15 while rising to prepare distortions as follows $20.30,10,25$, respectively, and statistical analysis shows highly significant differences degree of $\leq 0.01$.

Table-2- shows that the treatment with after 15 ,there is increased number of sperm normal to $55 \%$ while the number of no head is decreased to $3 \%$ after it was $20 \%$ and the Balloon head is decreased from $30 \%$ to $15 \%$ as well as in relation to the thread head decreased from $10 \%$ to $3 \%$ either no head curved tail has decreased from $25 \%$ to $23 \%$ in total, there are highly significant differences degree of $\leq 0.01$.

Table- 3-shows the effect of treated with ESO for where it was ratio of normal sperms comparison with UVC ( $15 \%$ became to $62 \%$ ), no head decreased from $20 \%$ to $8 \%$, the Balloon head decreased from $30 \%$ to $13 \%$,the thread head from $10 \%$ to $3 \%$ and the no head curved tail from $25 \%$ to $15 \%$,so this show the total number and the presence of highly significant differences in degree of $\leq 0.01$.

It can be concluded that, UVC irradiation a toxic effect leading to some degree of sperm head abnormalities. While treatment with ESO may be resulting in adversely influncing mammalian germ cell metabolism, which lowering the frequencies of sperm head abnormalities.

\section{References:}

[1]. www.epa. gov/ ozone/strathome, html,2010. EPA: United States Enviromental Protection Agency, air and radiation 6205J.

[2]. Wäster, P. K. \& Ollinger, K. M. (2009). Redox-dependent translocation of p53 to mitochondria or nucleus in human melanocytes after UVA- an UVB- induced apoptosis. Journal of Investigative Dermatology, Vol.129:1769-1781.

[3]. Armstrong, B. K. \& Kricker, A. (2001). The epidemiology of UV induced skin cancer. Journal of Photochemistry and Photobiology B, Vol.63:8-18

[4]. Gruijl, F. R.; Van Kranen, H. J. \& Mullenders, L. H. (2001). UV-induced DNA damage, repair, mutations and oncogenic pathways in skin cancer. Journal of Photochemistry and Photobiology B, Vol.63:19-27.

[5]. Sun F., Ko E., and Martin R. H.( 2006), Is there arelationship between sperm chromosome abnormalities and sperm morphology?, Reproductive Biology and Endocrinology, 4(1): 1-2.

[6]. Saacke RG.( 2001). What is a BSE-SFT standards: the relative importance of sperm morphology: an opinion. Proc Soc Theriogenol;81-7.

[7]. Barth AD, Oko RJ.( 1989). Abnormal morphology of bovine spermatozoa. Ames, IA: Iowa State Press (Blackwell).

[8]. WHO(1992): who laboratory manual for the examination of human semen and sperm-cervical mucus interaction, $3^{\text {rd }}$ edition, New York, Cambridge University Press.

[9]. Okasha. M. A. M,Abubakar. M. S,Bako. I. G (2008).Study of the Effect of Aqueous Hibiscus Sabdariffa Linn Seed Extract on Serum Prolactin Level of Lactating Female Albino Rats . European Journal of Scientific Research Vol.22(4) :575-583.

[10]. Coulson, C., Jenkins, J. J. Exp. Clin. Assist. Rep. 2 (2005) 5.3. Esiyok D. Marketing and utilization of rocket in turkey. In: Padulosi S, Pignone D, editors. Rocket: A mediterranean crop for the world. Rome, Italy: International plant genetic resources institute( Report of a workshop 13-14 december 1996). 
[11]. Bennett RN, Mellon FA, Botting NP, Eagles J, Rosa EA, Williamson G.( 2002). Identification of the major glucosinolate (4mercaptobutyl glucosinolate) in leaves of Eruca sativa 1.(salad rocket)Phytochemistry.61:25-30.

[12]. Lazzeri L, Errani M, Leoni O, Venturi G.(2004). Eruca sativa spp.Oleifera: A new non-food crop. Ind Crop Pro.20:67-73.

[13]. Aggarwal, B. B. and Shishodia, S. (2006): Molecular targets of dietary agents for prevention and therapy of cancer. Biochem. Pharmacol.71: 1397-1421.

[14]. Kim, S. J., JIN, S. and Ishii, G. (2004). Isolation and structural elucidation of 4-(B-d-Glucopyranosyl-disulfanyl) butyl glucosinolate from leaves of rocket salad (Eruca sativa L.) and its antioxidative stress. Bio. Sci. Biotechnol. Biochem.: 68 (12): 2444 -2450.

[15]. Wyrobek A.J. and Bruce W.R. (1975) Natl. Acad. Sci. USA, 72, 4425-4429.

[16]. Health Physics Society (1956) Specialists in Radiation Safety, HPS. 